\title{
Yucca Mountain Project Surface Facilities Design
}

\author{
P. W. McDaniel, \\ Bechtel SAIC Company, LLC \\ 1180 Town Center Drive \\ Las Vegas, $N V 89144$ \\ Email preston_mcdaniel@ymp.gov \\ N. R. Brown, \\ Bechtel SAIC Company, LLC \\ 1180 Town Center Drive \\ Las Vegas, NV 89144 \\ Emailneil_brown@ymp.gov \\ P. G. Harrington, \\ DOE, ORD \\ DOE Office of Repository Development \\ PO Box 364629 \\ N. Las Vegas, NV United States 89036 \\ Email paul_harrington@ymp.gov \\ J. T. Gardiner, \\ $D O E, O R D$ \\ DOE Office of Repository Development \\ PO Box 364629 \\ N. Las Vegas, NV United States 89036 \\ Emailjim gardiner@ymp.gov
}

\author{
L. J. Trautner, \\ Bechtel SAIC Company, LLC \\ 1180 Town Center Drive \\ Las Vegas, NV 89144 \\ Email larry_trautner@ymp.gov
}

\begin{abstract}
With the recent designation of the Yucca Mountain site as a proposed repository for the disposal of commercial spent nuclear fuel, DOE spent nuclear fuel and high-level waste, work is proceeding on the design of surface facilities to receive, unload, and package the waste into waste packages for emplacement in the repository.

This paper summarizes recent progress in the design of these surface facilities.
\end{abstract}

\section{PROJECT DESCRIPTION}

The U.S. has spent more than 40 years evaluating methods for long-term management of radioactive wastes. Throughout the 1960 s and 1970 s, the U.S. Atomic Energy Commission and its successor agencies, the Energy Research and Development Administration and the U.S. Department of Energy (DOE), continued to analyze options for nuclear waste management. After analyzing a range of options, experts agreed that disposal in mined geologic repositories was the preferred long-term environmental solution for the management of spent nuclear fuel and high-level radioactive waste. In accordance with the Nuclear Waste Policy Act of 1982 (NWPA), as amended (42 U.S.C. 10101 et seq.), the site designation process has been completed for the Yucca Mountain site as the proposed repository for the disposal of the nation's spent nuclear fuel and high-level radioactive waste. DOE is now in the process of preparing a License Application to the U.S. Nuclear Regulatory Commission (NRC) for authorization to construct the proposed repository at Yucca Mountain. 
The proposed Yucca Mountain repository consists of surface and subsurface facilities designed to support waste handling, emplacement, potential retrieval, and permanent closure of the repository. These systems and facilities are being designed to protect the health and safety of the public and site workers and to meet preclosure and postclosure repository performance objectives. This paper presents the design for the surface facilities that make up the proposed repository and a description of the surface facility operations.

In general, the proposed repository surface facilities will perform the following basic functions:

- Receiving spent nuclear fuel and high-level radioactive waste in transportation casks certified by the NRC from rail and truck transporters

- Unloading, handling, and packaging spent nuclear fuel and high-level radioactive waste into waste packages suitable for underground emplacement

- Monitoring operations and repository system performance to ensure the safety of workers and the public.

These basic functions, together with the project design requirements (NRC regulations, Environmental Protection Agency regulations, NWPA, Occupational Safety and Health Act requirements, Quality Assurance requirements, etc.), are the bases for the Yucca Mountain surface facilities design.

\section{DESIGN DEVELOPMENT}

Commercial spent nuclear fuel can be handled in dry hot cells, or wet in fuel processing pools. The decision on dry versus wet handling has a major effect on facility layout, requirements, design, construction and operations. Several evolutions of the surface facilities design have taken place related. to the dry and wet fuel handling approaches.

In 1998, DOE prepared the Viability Assessment of a Repository at Yucca Mountain, DOE/RW-0508. This document described, discussed, and evaluated a "snapshot" of the design in its evolutionary process. The Viability Assessment included a wet handling system for commercial spent nuclear fuel with a single Waste Handling Building. The Waste Handling Building housed facilities and equipment required to remove spent nuclear fuel assemblies and other high-level radioactive waste forms from transportation casks; handle the casks and wastes within the facility; place the wastes into disposal containers; close and inspect the containers; and load the waste packages (loaded, sealed, and tested) onto the waste package subsurface transporter for transport underground for emplacement.

The Site Recommendation design, prepared in 2001, included a wet handling design for commercial spent nuclear fuel with 5,000 metric tons of heavy metal (MTHM) fuel blending pools in a single Waste Handling Building. Changes were made to the Viability Assessment building design to accommodate an expanded capacity spent fuel pool for fuel blending.

A recent evaluation of dry versus wet handling was completed in 2002. The Site Recommendation design concept of constructing one large integrated waste handling building was compared to a phased approach with several buildings. Options examined were: all wet processing in one large pool (similar to the Site Recommendation design); all dry processing; and all wet processing in a phased approach with several smaller buildings rather than one large building. The recommended approach was to implement:

- A primarily dry processing approach with wet processing for off-normal spent fuel. This approach is similar to the facilities at La Hague, France, that use the wet system for items that could disnupt and delay processing within the dry system.

- Construction and operation of the surface facilities in phases to support smaller waste receipt rates during initial operation followed by construction and operation of larger facilities to accommodate maximum throughput.

The primary advantages of the preferred option are (a) greater flexibility, (b) ability to incorporate lessons learned, (c) lower initial facility cost, and (d) less risk to the project schedule for initial operations. The design for the Yucca Mountain surface facilities follows this approach and includes multiple waste handling facilities with systems for handling waste forms dry, with some wet capability to handle offnormal commercial spent nuclear fuel, as required. Note that this design approach is still under development and DOE has not adopted this change yet. 


\section{SURFACE FACILITES DESIGN}

The primary waste handling facilities in the surface design are the Transporter Receipt Building. Dry Transfer Facility 1, Dry Transfer Facility 2, and the
Remediation Building. The waste handling process through these buildings is shown in Figure 1.

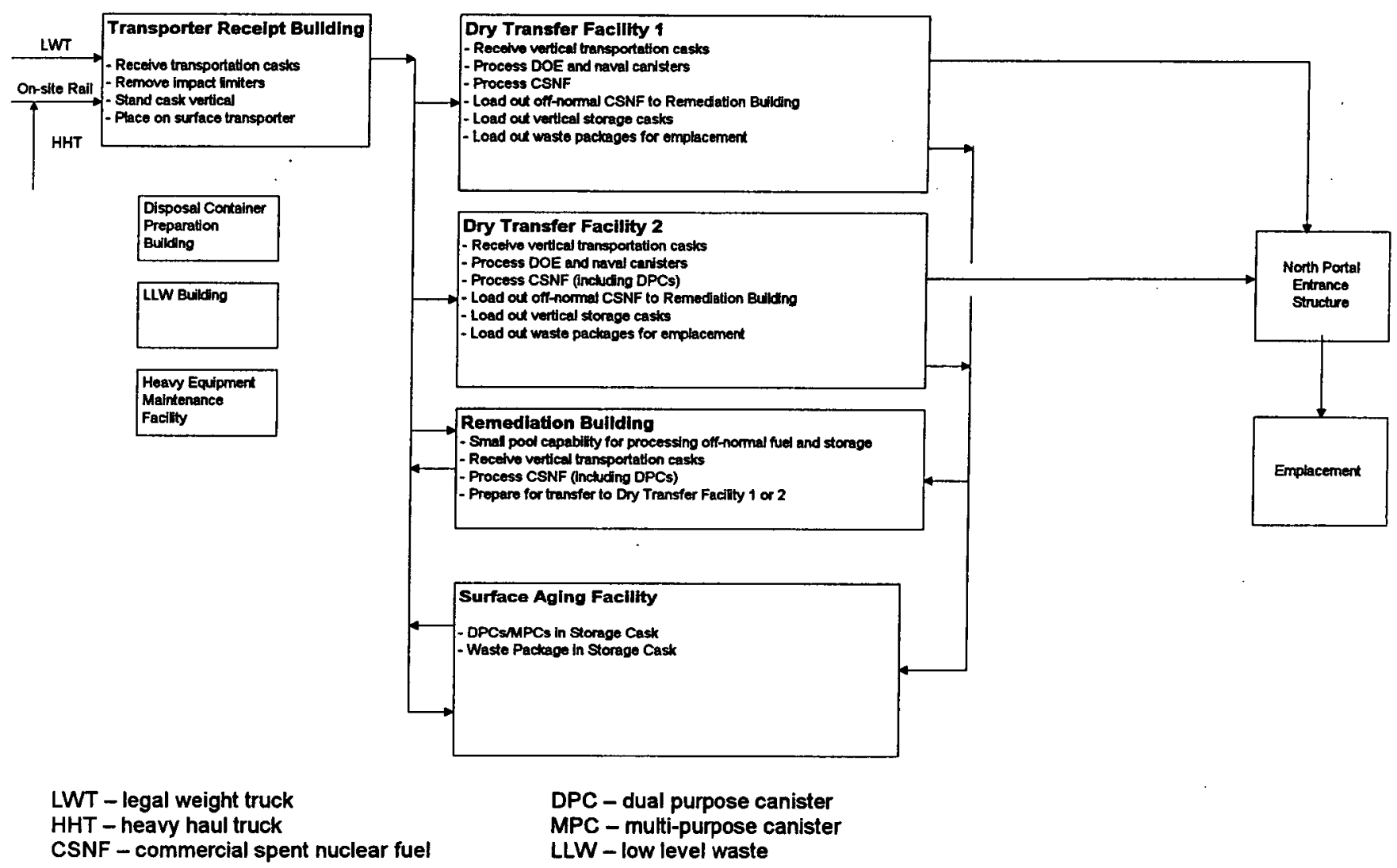

Figure 1. Surface Facilities Waste Handling Process

Rail and truck transportation casks containing the waste shipments are routed to the Transporter Receipt Building where the transportation casks are received and loaded onto surface transporters, which are used to transport the waste between surface facilities. From the Transporter Receipt Building, the transportation casks are moved to either Dry Transfer Facility 1 or 2. In Dry Transfer Facility 1 and 2, the transportation cask is opened and the waste form is removed and placed into a waste package. The waste package is moved from the loading area, using the surface transporter, to a welding station where the waste package lids are welded and inspected. From the welding station, the sealed waste package is moved to the load out area where it is loaded onto the subsurface transporter in preparation for emplacement. The Remediation Building is available, as needed, to handle wet storage of off-normal commercial spent nuclear fuel. The Surface Aging Facility, with up to 1,000 MTHM capacity, is also available, as needed, to age commercial spent nuclear fuel and to provide a surge capacity capability for additional flexibility in waste handling operations. Other surface facilities provide support to waste processing operations. 


\section{III.A. Transporter Receipt Building}

The primary functions of the Transporter Receipt Building are to (1) receive loaded transportation casks, (2) remove personnel barriers and impact limiters from the casks, (3) stand the casks vertically, and (4) place the casks on the surface transporter for movement to Dry Transfer Facility 1 or 2 . Legal weight trucks and rail carriers are received directly into the Transporter Receipt Building. The material handling system in the Transporter Receipt Building will provide the capability to receive and inspect transportation casks from the carrier and then prepare the casks for unloading in Dry Transfer Facility 1 or 2. Empty casks are returned from Dry Transfer Facility 1 or 2 to the Transporter Receipt Building and prepared for shipment offsite for re-use.

The Transporter Receipt Building is sized to process 100 percent of the repository waste stream transportation casks.

\section{III.B. Dry Transfer Facility 1}

In Dry Transfer Facility 1, the loaded transportation cask is received in the cask preparation area, the cask is sampled, vented, and the cover bolts are removed. The cask is then moved to the unloading cell where the waste is transferred to the waste package. The empty cask is then moved back to the cask preparation area, where the cover and cover bolts are reinstalled. The loaded waste package is moved to a welding station where the lids are welded, the package is inerted, weld stress mitigation is performed, and the welds are inspected. The sealed waste package is then loaded onto a shielded . subsurface transporter in preparation for emplacement.

Dry Transfer Facility 1 does not include the capability to process commercial spent nuclear fuel received in dual purpose canisters; this approach is used to keep the building size to a minimum to allow it to be constructed and operable on the project schedule for initial operations. The capability to process dual purpose canisters is provided in Dry Transfer Facility 2 and the Remediation Building.

Dry Transfer Facility 1 is sized to process approximately one-third of the repository waste stream rate for emplacement packaging.

\section{III.C. Dry Transfer Facility 2}

Dry Transfer Facility 2 performs the same functions as Dry Transfer Facility 1 with the addition of the capability to process commercial spent nuclear fuel received in dual purpose canisters. Dual purpose canisters are received at the repository welded closed and must be cut open to remove the waste form.

Dry Transfer Facility 2 is larger than Dry Transfer Facility 1 and is sized to process approximately twothirds of the repository waste stream rate for emplacement packaging.

\section{III.D. Remediation Building}

The Remediation Building houses structures, systems, and components for wet handling of off-normal and young (hot) commercial spent nuclear fuel. Facilities are also provided in the Remediation Building to repair waste packages. A fuel pool will have the capability to contain approximately 200 MTHM of commercial spent nuclear fuel.

Waste forms that are ready for loading in a waste package will be placed in a canister or transfer cask and closed for transfer from the Remediation Building to Dry Transfer Facility 1 or 2 for packaging the waste in a waste package.

$$
\text { III.E. Aging Facility }
$$

The Aging Facility provides space for staging waste. This staging capability will enable commercial spent nuclear fuel to be aged as necessary to meet waste package thermal limits and also to provide a surge capacity capability for additional flexibility in waste processing operations. Approximately 1,000 MTHM of aging capacity is provided in the design.

\section{SURFACE FACILITY LAYOUT AND PHASED CONSTRUCTION}

The geological repository operations area is a protected area where the radioactive waste will be received from offsite transportation carriers, packaged, and emplaced in the repository. Figure 2 depicts the North Portal area within the geological repository operations area and shows the design locations of the major surface facilities. The site layout is currently being evaluated to address issues related to concurrent construction and operations in the North Portal area, as described below. The phased approach to surface facility 


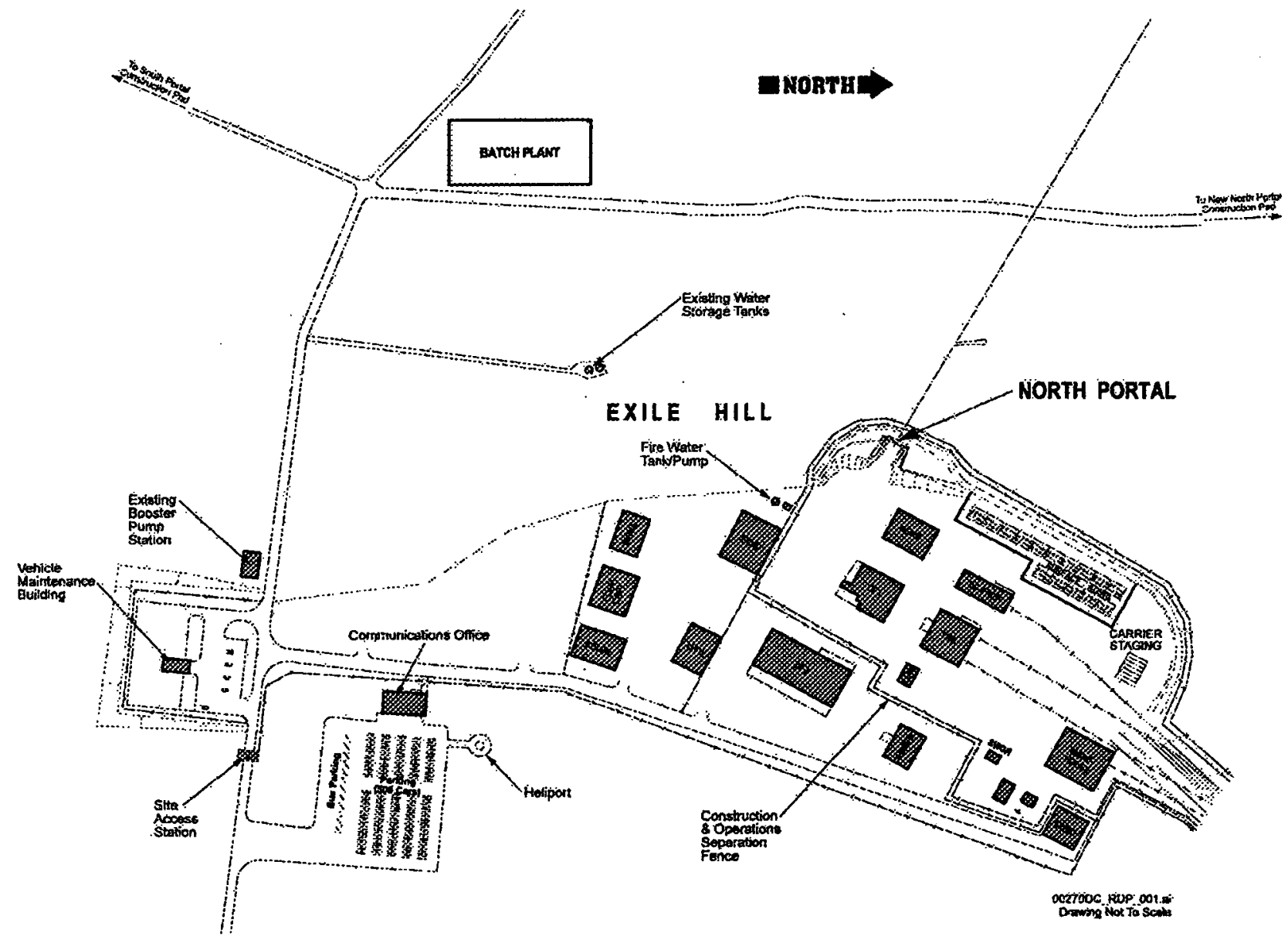

Primary Waste Handling Facilities:

DF1 - Dry Transfer Facility 1

DF2 - Dry Transfer Facility 2

TRB - Transporter Receipt Building

Remed - Remediation Building

Note: This figure provides an overall plan view of the North Portal surface facilities illustrating the building locations, balance-of-plant facilities, and general access roads to the facilities.

Figure 2. Surface Facility Layout

construction will require that the design consider concurrent construction and operations to assure that construction activities will not interfere with operational activities, or in certain instances, initiate or contribute to an abnormal occurrence or an accident. As the design progresses, the following requirements will be considered to ensure that operations are not adversely affected by concurrent construction activities: physical barriers and separation; security access and radiation controls; waste transportation and routing; and hazards analysis and event sequences.

\section{DESIGN EVALUATIONS}

The safety and design analyses conducted by the Yucca Mountain Project to date demonstrate that the proposed repository design can operate safely and meet established performance objectives. These safety analyses are ongoing activities that will continue, integrated with the design process, to assure and document the safety of the design as it progresses beyond the conceptual stage to preliminary and detailed design. 


\section{V.A. Safety Evaluations}

Importance to safety is described in 10 CFR 63.2, with reference to structures, systems, and components, as those engineered features of the repository geologic operations area whose function is to provide reasonable assurance that the waste can be received, handled, packaged, stored, emplaced and retrieved without exceeding the requirements of 10 CFR 63.111(b)(1) for Category 1 event sequences, or to prevent or mitigate Category 2 event sequences that could result in radiological exposures exceeding the values specified in 10 CFR 63.111(b)(2) to any individual located on or beyond any point on the boundary of the site. Importance to waste isolation, with reference to the design of the engineered barrier system and characterization of natural barriers, means those engineered and natural barriers whose function is to provide a reasonable expectation that high-level waste can be disposed of without exceeding the requirements of 10 CFR 63.113(b) and (c).

The structures, systems, and components important to safety are identified through the use of sensitivity and uncertainty analyses and the use of the classification process. A preliminary evaluation of the design has identified the structures, systems, and components that are important to safety and important to waste isolation. The Quality Assurance classification levels of the structures, systems, and components important to safety and important to waste isolation are established and re-evaluated as the repository design evolves during the iterative design process.

\section{V.B. Project Design Issues}

A final decision will need to be made regarding the proposed design change of a phased approach to construction and operations. A number of evaluations of the surface facility designs will be conducted, in addition to the standard design development processes, to address areas of uncertainty in the project. These evaluations include:

- Waste shipments to the Yucca Mountain Project will arrive in a combination of truck and rail deliveries. The capacity of the surface facilities to handle different combinations of truck and rail shipments will be evaluated to determine throughput capacities and potential impacts to the surface facilities. These evaluations will be coordinated with the DOE transportation projects associated with the Yucca Mountain Project.
- The phased approach to initial plant operations requires concurrent surface facility operations and construction. The concurrent operations/construction approach will be evaluated to determine design features needed to satisfy design basis and preclosure safety evaluation requirements.

- A prototype test program is being developed to assist in finalizing the designs for the waste dry handling equipment, waste package closure and weld stress relief systems, the surface and subsurface transporters, and waste package emplacement systems. Other equipment and systems may be added to the prototype test program as the design progresses.

- Safeguards and security requirements are currently under review and may result in revisions to the surface facilities design. Potential design changes may result from DOE vulnerability assessments, Homeland Security requirements, and NRC requirements. As revised safeguards and security requirements are identified, they will be evaluated for impacts to the surface facility designs.

- The requirements for aging/staging of commercial spent nuclear fuel have not yet been finalized. Surface facility design features for aging/staging will be evaluated and revised, as needed, as the requirements are updated.

- The design does not include design features for fuel characterization and fuel burn-up measurements. If it is determined that fuel characterization and fuel burn-up measurement systems are required, an evaluation will be performed to determine the impact on Dry Transfer Facility 1 and 2 and the Remediation Building.

\section{CONCLUSIONS}

The surface facilities design satisfies the requirement to accommodate the range and quantities of waste forms planned for disposal at the proposed Yucca Mountain repository. The phased approach to construction has been determined to be viable, provides opportunities to optimize future facility designs based upon lessons learned, and allows repository operations to begin within the current project schedule. Uncertainties in the design have been identified and are being addressed to ensure that 
the design presented to the NRC in the License Application meets regulatory requirements. 